\title{
INFLUENCE OF MOTHER RHIZOME RETRIEVAL AND ORGANIC TREATMENT OF THE RETRIEVED PLANTS ON ECONOMIC YIELD OF GINGER AT SALYAN, NEPAL
}

\author{
M. Basnet ${ }^{1 *}$ and H. Gurung ${ }^{2}$ \\ ${ }^{1}$ Paklihawa Campus, Institute of Agriculture and Animal Science \\ ${ }^{2}$ Senior Agriculture Development Officer, Ministry of Agriculture, Land management and Co-operatives \\ *manoj@iaas.edu.np
}

\begin{abstract}
An experiment was conducted at Salyan, Nepal to assess the mother rhizome retrieval and organic treatment of the same retrieved plant on economic yield of ginger during 2015/16.'Kapurkot Aduwa-1', a superior Nepalese variety was used for this experiment. Two dates i.e. 1 September and 7 September were used as a time of retrieval factor and seven organic treatments i.e. Trichoderma, Jeevatu, Bordeaux paste, mixture of neem and timur dust, vermicompost, jholmal and control as second factor and these 14 treatment combinations were laid out in factorial randomized block design with three replications. The plant height, leaf number, tiller number was found to be significantly highest with vermicompost treatment on all days 5 days interval after harvesting of the mother rhizome whereas the lowest was observed at control. The mother rhizome yield and fresh rhizome was found to be significantly highest on vermicompost applied field with $1.7 \mathrm{t} / \mathrm{ha}$ and $22.8 \mathrm{mt} / \mathrm{ha}$ respectively and lowest fresh rhizome yield (15.5. t/ha) was found with control. The disease yield was significantly lowest $(0 \mathrm{t} / \mathrm{ha})$ and highest $(0.2 \mathrm{t} / \mathrm{ha})$ with the control. Benefit cost ratio was found to be significantly highest (1.74) and lowest at control (1.32).
\end{abstract}

Keywords: leaf, plant height, spices, tiller.

\section{INTRODUCTION}

Ginger (Zingiber officinale) is an important commercial spices crop in tropical and subtropical countries. The useful and edible part of this crop is the rhizome. It is used worldwide as spices for flavoring in a number of foods and food-products and also used in medicines (Lawrence, 1984). Ginger being spice crop has potential adopted as well as to be adopted by farmers for commercial cultivation. But major constraint is its high cost of cultivation since about $50 \%$ of the cost of cultivation incurred in purchase of seed rhizome only (GRP, 2010). So, practice of mother rhizome retrieval (during off season) before harvesting of ginger can be good practice and economical for farmers. Up to $90 \%$ of seed rhizome can be retrieved if good retrieval practice is used (GRP, 2010). But mother rhizome retrieval may lead to rhizome rot infestation, due to infection of rhizome from the point of rhizome separation. So, rhizome should be treated immediately along with soil treatment in order to reduce the risk of insect pest and disease damage.

It has been estimated that total annual production of ginger in Nepal is 271,863 $\mathrm{mt}$ from 21,869 ha of land with the average productivity of $12.43 \mathrm{mt} / \mathrm{ha}$ during 2015/16 (ABPSD, 2015/16) which is lower than its potentiality (30 mt/ha of the variety Kapurkot Aduwa-1). Despite of the favorable environment conditions in the mid-hills for production, national productivity is stagnant and could not exceed $11.40 \mathrm{mt} / \mathrm{ha}$ which was mainly due to the many biotic factors mainly rhizome rot, rhizome fly, white grub and other minor diseases and insect pests which are randomly noticed in farmer's field at various ginger and turmeric growing places and soil fertility degradation (GRP, 2010). 
Chemical treatment increase the cost of production and continuous use of the chemicals results in accumulation harmful chemical residues in soil as well as plant products causing serious environmental pollution, deleterious effect to non target beneficial soil microorganism. In search of eco-friendly approach several researchers investigated on organic products, bio-agents, plant extract for the management of the disease (Anandaraj and Sharma, 2003; Ambia, 2006). Now a days Trichoderma $s p$ is frequently used as a bio-agent against soil borne fungal pathogens (Ahmmed and Hossain, 2006). Moreover, soil amendment using poultry wastes and saw dust are now being considered as environment friendly approach that make the soil suppressive improving the antagonistic activities of the soil microorganisms. Anandaraj and Sharma (2003) developed an integrated approach to disease management by soil treatment using selective mixture of fungicide with Trichodermaharzianum. Usman et al. (2006) reported that Trichoderma harzianum was very effective in controlling the disease. Application of Neem cake $2 \mathrm{t} / \mathrm{ha} \pm$ timur dust $50 \mathrm{~kg} / \mathrm{ha}$ resulted comparatively lower diseased tillers and rotted rhizome yield $(1.19 \mathrm{t} / \mathrm{ha})$ and therefore rhizome rot can be minimized with the use of neem cake \pm timur dust (GRP, 2010). Significant yield of $26.82 \mathrm{t} / \mathrm{ha}$ was obtained with the application of timur dust @ $50 \mathrm{~kg} /$ ha. Use of Jeevatu and Jeevatu based organic liquid manure, was found to have played vital role in soft rot control and no further spreading of the disease (Poudyal 2012). According to K.C. (2003), harvesting of mother rhizome provided nearly twice the economic return as compared to no mother rhizome harvest.Vermi-compost contains the balanced nutrient as well as plant growth hormones and is resistant to disease attack (Arancon et al., 2004; Al-Dahmani et al., 2003; Frankenberger and Arshad, 1995). Similarly, vermi-compost being complete organic manure served on improving soil structure and microbial biomass (Dauda et al., 2008; Jahan et al., 2014).

\section{MATERIALS AND METHODS}

This experiment was conducted in three ginger famers group (Suntakuri and Laligurans of Chaadekaranje VDC and Siddha Binayak of Bame VDC) of Salyan district of Nepal. Two factorial experiments was laid out in a Completely Randomized Block design with three replications. The first factor consisted of two dates of mother rhizome retrieval i.e. 1 September and 7 September, 2015 whereas second factor has seven organic treatments i.e. Trichoderma, Jeevatu, Bordeaux paste, mixture of neem and timur dust, vermicompost, jholmal and control. There were 14 treatments which were replicated thrice on three groups of Salyan district. The rhizomes were planted at $30 \times 30 \mathrm{~cm}$ on every plot having 5 rows with 10 plants per row on the area of $4.5 \mathrm{~m}^{2}$. There were 50 plants per plot which were categorized as inner 24 observational plants and other remaining 26 boarder plants.

Each plot were supplied with well-rotted FYM (Farm Yard Manure) at the rate of 30 ton/ha and nitrogen, phosphorous and potassium at 75:50:50 kg/ha. Half of the nitrogen and full dose of FYM, phosphorus and potassium were applied as basal dose before transplanting. Rest half of nitrogen was top-dressed at 60 days after transplantation. Nitrogen was supplied through Urea $(46 \% \mathrm{~N})$ and DAP, phosphorus through DAP $(18 \% \mathrm{~N}$ and $46 \% \mathrm{P})$ and potash through Murate of potash $(60 \% \mathrm{~K})$.

The detail of the treatment description is described as:

\section{Factor A: Six organic treatments along with control}

\section{Mother Rhizome retrieval (MRR) + Use of commercial product of Trichoderma: The commercial} product was cultured in lab to test its viability before application. Commercial product of Trichoderma with concentration of $2 \times 106 \mathrm{cfu}$ per $\mathrm{ml}$ was used. First solution was prepared in 1:9 ratio of 
Trichoderma. Final solution was prepared by again mixing 9 part of water on 1 part of previously prepared solution. It was applied at the rate of 3 lit per square meter.

2. MRR + Jeevatu: First slurry was made by mixing 1 lit jeevatu on $25 \mathrm{~kg}$ compost and 49 litres of water. Then it was packed in 500 gauge plastic bag and pressed inside the pit to prepare liquid manure. Liquid manure was stirred thoroughly twice a week by hand. The liquid was ready within one week. One part of organic jeevatu based organic manure was combined with two part of water which was our treatment mixture. It was applied at the rate of 5 lit solutions per square meter as pre the company prescription.

3. MRR + Use of bordeaux paste: $1 \%$ bordeaux mixture was used. It was prepared by mixing 100 gm of Copper sulphate on separate bucket containing 5 liters of water, whereas another $100 \mathrm{gm}$ of lime was mixed on another bucket containing 5 liters of water. Finally, the two solutions were mixed thoroughly. It was applied at the rate of 1 lit solution per square meter.

\section{MRR + Application of Neem cake $2 \mathrm{t} / \mathrm{ha}+$ timur dust $50 \mathrm{~kg} / \mathrm{ha}$}

5. MRR + Use of cow urine + vermicompost: The fresh cow urine was diluted by mixing 9 lit of water on 1 lit of urine. In addition, $2 \mathrm{~kg}$ of vermi-compost was mixed on the prepared solution. It was applied at the rate of 5 lit per square meter.

6. MRR + Use of Jholmal: It was prepared by mixing locally available plant parts which have high repellent characteristics. They were first decomposed by mixing 10 types of plants on 10 litres of water for 1 month on closed bucket. The decomposed mixture was diluted by mixing 9 litres of water on 1 liter of it. It was applied at the rate of 5 liter per square meter.

\section{Control (no MRR practice).}

Factor B: The treatments were applied on two date.

1. $1^{\text {st }}$ of September and

2. $7^{\text {th }}$ of September

In addition data were taken at 5 days interval after mother rhizome harvesting and treatment applications which were carried out on a same day.

\section{RESULT AND DISCUSSION}

\section{Plant height, leaf number and tiller number per plant}

The plant height was found to be significantly highest with the application of vermicompost i.e. $82.2,85.3$ and $88.3 \mathrm{~cm}$ on 5 days interval after harvesting of the mother rhizome whereas the lowest plant height was observed at control with $61.5,64.3$ and $66.7 \mathrm{~cm}$ on 5 days interval (table 1). 
Table 1: Plant height, Leaf number and tiller number per plant of ginger at different organic treatments at Salyan, Nepal, 2016.

\begin{tabular}{lccccccccc}
\hline Treatments & \multicolumn{3}{c}{ Plant height $(\mathrm{cm})$} & \multicolumn{3}{c}{ Leaf no per plant } & \multicolumn{3}{c}{ Tiller no per plant } \\
\cline { 2 - 10 } & 5 & 10 & 15 & 5 & 10 & 15 & 5 & 10 & 15 \\
\hline Organic pesticide(Main factor) & & & & & & & & \\
\hline Trichoderma & $79.2^{\mathrm{ab}}$ & $80.8^{\mathrm{ab}}$ & $82.7^{\mathrm{ab}}$ & $18.5^{\mathrm{a}}$ & $20^{\mathrm{bc}}$ & $22^{\mathrm{ab}}$ & $14.8^{\mathrm{a}}$ & $15.3^{\mathrm{a}}$ & $16^{\mathrm{a}}$ \\
Jeevatu & $78.5^{\mathrm{ab}}$ & $79.5^{\mathrm{ab}}$ & $81.5^{\mathrm{ab}}$ & $18.1^{\mathrm{a}}$ & $19.5^{\mathrm{ab}}$ & $20.6^{\mathrm{ab}}$ & $13.8^{\mathrm{a}}$ & $14.8^{\mathrm{a}}$ & $15.5^{\mathrm{a}}$ \\
Bordeaux paste & $78.5^{\mathrm{ab}}$ & $80.3^{\mathrm{ab}}$ & $81.7^{\mathrm{ab}}$ & $21.1^{\mathrm{a}}$ & $22.5^{\mathrm{ab}}$ & $23.8^{\mathrm{ab}}$ & $14.1^{\mathrm{a}}$ & $17.1^{\mathrm{a}}$ & $17.8^{\mathrm{a}}$ \\
Neem+timbur & $80.5^{\mathrm{ab}}$ & $82.3^{\mathrm{ab}}$ & $84.3^{\mathrm{ab}}$ & $19.8^{\mathrm{a}}$ & $22.6^{\mathrm{ab}}$ & $24.1^{\mathrm{ab}}$ & $13.8^{\mathrm{a}}$ & $15^{\mathrm{a}}$ & $15.6^{\mathrm{a}}$ \\
Vermicompost & $82.2^{\mathrm{a}}$ & $85.3^{\mathrm{a}}$ & $88.3^{\mathrm{a}}$ & $21.1^{\mathrm{a}}$ & $24.6^{\mathrm{a}}$ & $26.6^{\mathrm{a}}$ & $17.1^{\mathrm{a}}$ & $17.6^{\mathrm{a}}$ & $18.3^{\mathrm{a}}$ \\
Jholmal & $74.2^{\mathrm{ab}}$ & $76.2^{\mathrm{b}}$ & $77.5^{\mathrm{b}}$ & $19.1^{\mathrm{a}}$ & $22^{\mathrm{b}}$ & $21.6^{\mathrm{b}}$ & $15.8^{\mathrm{a}}$ & $16.5^{\mathrm{a}}$ & $16.6^{\mathrm{a}}$ \\
Control & $61.5^{\mathrm{b}}$ & $64.3^{\mathrm{c}}$ & $66.7^{\mathrm{c}}$ & $17.1^{\mathrm{b}}$ & $18.8^{\mathrm{c}}$ & $20.5^{\mathrm{b}}$ & $13.7^{\mathrm{a}}$ & $14.6^{\mathrm{a}}$ & $14.6^{\mathrm{a}}$ \\
\hline CV\% & 7.5 & 7.6 & 7.9 & 21.8 & 27.6 & 22.8 & 12.8 & 11.5 & 10.9 \\
P(0.05) & $*$ & $*$ & $*$ & $\mathrm{NS}$ & $*$ & $*$ & $\mathrm{NS}$ & $\mathrm{NS}$ & $\mathrm{NS}$ \\
LSD & 12.91 & 11.48 & 10.96 & 3.3 & 3.02 & 3.920 & 1.61 & 2.69 & 2.5 \\
\hline Date (Factor B) & & & & & & & & & \\
\hline 1September & $74.2^{\mathrm{a}}$ & $76.6^{\mathrm{a}}$ & $78.4^{\mathrm{a}}$ & $18.4^{\mathrm{a}}$ & $20.5^{\mathrm{a}}$ & $21.6^{\mathrm{a}}$ & $14^{\mathrm{a}}$ & $15.2^{\mathrm{a}}$ & $15.7^{\mathrm{a}}$ \\
7September & $78.5^{\mathrm{a}}$ & $80.2^{\mathrm{a}}$ & $82.3^{\mathrm{a}}$ & $20.1^{\mathrm{a}}$ & $22.3^{\mathrm{a}}$ & $23.9^{\mathrm{a}}$ & $15.6^{\mathrm{a}}$ & $16.5^{\mathrm{a}}$ & $17^{\mathrm{a}}$ \\
\hline CV\% & 7.5 & 7.6 & 7.9 & 21.8 & 27.6 & 22.8 & 12.8 & 11.5 & 10.9 \\
P (0.05) & $\mathrm{NS}$ & $\mathrm{NS}$ & $\mathrm{NS}$ & $\mathrm{NS}$ & $\mathrm{NS}$ & $\mathrm{NS}$ & $\mathrm{NS}$ & $\mathrm{NS}$ & NS \\
LSD & 6.90 & 6.14 & 5.86 & 1.78 & 1.61 & 2.09 & 3.01 & 1.44 & 1.3 \\
\hline
\end{tabular}

"denotes significantly different at $P<0.05$ respectively. Means within column followed by the same letter are non-significantly different at $5 \%$ level.

Similarly, the leaf number per plant was also found to be significantly highest with the application of vermicompost i.e. 21.1, 24.6 and $26.6 \mathrm{~cm}$ on 5 days interval after harvesting of the mother rhizome whereas the lowest leaf number was observed at control with $17.1,18.8$ and $20.5 \mathrm{~cm}$ on 5 days interval (table 1). The tiller number per plant was found to be significantly highest with the application of vermicompost i.e. 17.1, 17.6 and 18.3 on 5 days interval whereas the lowest was found at control i.e. $13.7,14.6$ and 14.6 on 5 days interval (table 1).

The maximum plant height, leaf number and tiller number per plant with the application of vermicompost was due to the improvement in growth due toavailability of plant growth regulators and humic acid from Vermicompost (Arancon et al., 2004). It is stated that earthworms by their activity produce humus or humus likesubstances which may promote nutrient uptake, internal metabolism and influenceprotein synthesis (Bachman and Metzger, 2008). Vermicompost also show hormone likeactivity due to generating auxin, gibberiline and cytokinin like compounds which alteredmorphological and physiological characteristics of plants. Beside, many growth promoting factors it brings useful microflora which helps in nitrate up take kinetics as reported by various authors (Atiyeh et al., 2000; de Brito-Alvarez 1995; Muscolo et al., 1999). Ahmad et al. (2009) also found the similar results.

The two different date of treatment application and the interaction effect of organic treatment and date were found to have no significant effect on plant height, leaf number per plant and tiller number per plant. 
Yield of mother rhizome, fresh rhizome and disease rhizome per hectare

The mother rhizome yield and fresh rhizome was found to be significantly highest with vermicompost applied field with $1.7 \mathrm{t} / \mathrm{ha}$ and $22.8 \mathrm{mt} /$ ha respectively and lowest $(15.5 \mathrm{t} / \mathrm{ha})$ was found with control. The disease yield was significantly highest $(0.2 \mathrm{t} / \mathrm{ha})$ with the control (table 2). The maximum yield of mother rhizome, fresh rhizome and minimum diseased rhizome yield might be due to the high uptake of readily available nutrients from vermicomopost which ultimately produced healthy and luxurious vegetative growth. Similar findings were also reported by Ahmad et al. (2009). The two different date of treatment application and the interaction effect of organic treatment and date were found to have no significant effect on mother rhizome, fresh rhizome and disease rhizome yield.

Table 2: Mother rhizome, fresh rhizome and disease rhizome yield of ginger at different organic treatments at Salyan, Nepal, 2016.

\begin{tabular}{|c|c|c|c|}
\hline Treatments & $\begin{array}{l}\text { Mother rhizome yield } \\
(\mathrm{t} / \mathrm{ha})\end{array}$ & $\begin{array}{l}\text { Fresh rhizome yield } \\
(\mathrm{t} / \mathrm{ha})\end{array}$ & $\begin{array}{c}\text { Disease rhizome yield } \\
(\mathrm{t} / \mathrm{ha})\end{array}$ \\
\hline \multicolumn{4}{|c|}{ Organic pesticide(Main factor) } \\
\hline Trichoderma & $1.1^{\mathrm{bc}}$ & $17.9^{\mathrm{ab}}$ & $0.05^{\mathrm{ab}}$ \\
\hline Jeevatu & $1.0^{\mathrm{c}}$ & $17.0^{\mathrm{b}}$ & $0.0^{\mathrm{a}}$ \\
\hline Bordeaux paste & 0.9 & $17.0^{\mathrm{b}}$ & $0.0^{\mathrm{a}}$ \\
\hline Neem+timbur & $1.5^{\mathrm{b}}$ & $18.4^{\mathrm{ab}}$ & $0.01^{\mathrm{ab}}$ \\
\hline Vermicompost & $1.7^{\mathrm{a}}$ & $22.8^{\mathrm{a}}$ & $0.0^{\mathrm{a}}$ \\
\hline Jholmal & $1.0^{\mathrm{c}}$ & $17.8^{\mathrm{ab}}$ & $0.01^{\text {an }}$ \\
\hline Control & $0.0^{\mathrm{d}}$ & $15.5^{\mathrm{c}}$ & $0.2^{\mathrm{b}}$ \\
\hline $\mathrm{CV} \%$ & 11.2 & 11.1 & 37.8 \\
\hline $\mathrm{P}(0.05)$ & $* *$ & $* *$ & $* *$ \\
\hline LSD & 0.23 & 1.69 & 0.08 \\
\hline \multicolumn{4}{|l|}{ Date (Factor B) } \\
\hline 1 September & $0.8^{\mathrm{a}}$ & $16.86^{\mathrm{a}}$ & $0.04^{\mathrm{a}}$ \\
\hline 7 September & $0.8^{\mathrm{a}}$ & $17.36^{\mathrm{a}}$ & $0.05^{\mathrm{a}}$ \\
\hline $\mathrm{CV} \%$ & 11.2 & 11.1 & 37.8 \\
\hline $\mathrm{P}(0.05)$ & NS & NS & NS \\
\hline LSD & 0.12 & 0.90 & 0.04 \\
\hline
\end{tabular}

** and ${ }^{*}$ denotes significantly different at $P<.001$ and $P<0.05$ respectively. Means within column followed by the same letter are non-significantly different at $5 \%$ level.

\section{Net return and benefit cost ratio}

Vermi-compost gave the highest net return (NRS. 637000) and benefit cost ratio (1.74) on ginger production whereas, control gave the lowest net return (NRs. 230000) and benefit cost ratio of 1.32 (table 3 ). 
Table 3: Detail of cost-benefit analysis of cauliflower production with organic manures

\begin{tabular}{lllllllllll}
\hline Treatments & $\begin{array}{l}\text { Mother } \\
\text { rhizome } \\
\text { yield } \\
\left(\mathrm{tha}^{-1}\right)\end{array}$ & $\begin{array}{l}\text { Price } \\
(\mathrm{Rs} \\
\left.\mathrm{ha}^{-1}\right)\end{array}$ & $\begin{array}{l}\text { Income } \\
(\mathrm{A})(\mathrm{Rs} \\
\left.\mathrm{ha}^{-1}\right)\end{array}$ & $\begin{array}{c}\text { Fresh } \\
\text { hizome } \\
\text { yield } \\
\left(\mathrm{tha}^{-1}\right)\end{array}$ & $\begin{array}{c}\text { Price } \\
(\mathrm{Rs} \\
\left.\mathrm{ha}^{-1}\right)\end{array}$ & $\begin{array}{c}\text { Income } \\
(\mathrm{B})(\mathrm{Rs} \\
\left.\mathrm{ha}^{-1}\right)\end{array}$ & $\begin{array}{c}\text { Gross } \\
\begin{array}{c}\text { Income } \\
(\mathrm{A}+\mathrm{B}) \\
\left(\mathrm{Rs} \mathrm{ha}^{-1}\right)\end{array}\end{array}$ & $\begin{array}{c}\text { Total } \\
\text { variable } \\
\text { cost (Rs } \\
\left.\mathrm{ha}^{-1}\right)\end{array}$ & $\begin{array}{c}\text { Net } \\
\text { return }\end{array}$ & $\begin{array}{c}\text { BC } \\
\text { ratio }\end{array}$ \\
\hline $\begin{array}{l}\text { Trichoderma } \\
\text { Jeevatu }\end{array}$ & 1.1 & 70000 & 77000 & 17.9 & 60000 & 1074000 & 1151000 & 790000 & 361000 & 1.45 \\
Bordeaux paste & 1 & 70000 & 70000 & 17 & 60000 & 1020000 & 1090000 & 773300 & 316700 & 1.40 \\
$\begin{array}{l}\text { Neem+timur } \\
\text { dust }\end{array}$ & 1.9 & 70000 & 63000 & 17 & 60000 & 1020000 & 1083000 & 764000 & 319000 & 1.41 \\
Vermi-compost & 1.7 & 70000 & 105000 & 18.4 & 60000 & 1104000 & 1209000 & 855000 & 354000 & 1.41 \\
Jholmal & 1 & 70000 & 119000 & 22.8 & 60000 & 1368000 & 1487000 & 850000 & 637000 & 1.74 \\
Control & 0 & 70000 & 0 & 15.5 & 60000 & 930000 & 930000 & 700000 & 230000 & 1.32 \\
\hline
\end{tabular}

\section{CONCLUSION}

From the analysis, it was found that vermi-compost manure had played significant role on vegetative growth parameters (plant height, leaf and tiller number per plant) and yield characters (mother rhizome, fresh rhizome and disease rhizome yield per hectare). Thus, it can be recommended to conduct trial based on the different doses of vermi-compost application on ginger cultivation since the vermicompost applied field has the highest $\mathrm{BC}$ ratio (1.74).

\section{REFERENCES CITED}

ABPSD. (2015/16).Statistical information on Nepalese agriculture 2015/16. Agri-Business Promotion and Statistics Division, Ministry of Agriculture and Cooperatives, Government of Nepal, Kathmandu, Nepal.

Ahmad, R., Azeem, M., \& Ahmed, N. (2009). Productivity of ginger by amendment of vermicompost and biogas slurry in saline soils. Pakistan Journal of Botany, 41(6), 3107-3116.

Ahmmed A.N.F., \& Hossain M.B. (2006). Management of Fusariurm wilt and nemic wilt of eggplant through some selected treatments. (Unpulbished master's thesis). Sher-e-Bangla Agricultural University, Dhaka, Bangladesh.

Al-Dahmani, J.H., Abbasi, P.A., Miller, S.A., \& Hoitink, H.A.J. (2003). Suppression of bacterial spot of tomato with foliar sprays of compost extracts under greenhouse and field conditions. Plant Disease, 87, 913-919.

Ambia, N. (2006). Control of rhizome rot of ginger through selected chemicals.bio-agent, plant extract and soil amendment. (Unpulbished master's thesis). Sher-e-Bangla Agricultural University, Dhaka, Bangladesh.

Anandaraj, M., \& Sharma, Y.R. (2003). Role of root infection in rhizome rot of ginger (Zingiber officinale Rose). Journal of Plantation Crops, 21, 140-143.

Arancon, N.Q., Edwards, C.A., Bierman, P., Welch, C., \& Metzger, J.D. (2004). Influences of vermicomposts on field strawberries- effects on growth and yields; Bioresource Technology, 93, 145-153.

Atiyeh, R.M., Edwards, C.A., Subler, S., \& Metzger, J. (2000). Earthworm-processed organic wasteas components of horticultural potting media for growing marigold and vegetable seedlings. Comp. Sci. Util., 8, 215-253.

Bachman, G.R., \& Metzger, J.D. (2008). Growth of bedding plants in commercial potting substrate amended with vermicompost. Biores. Technol., 99, 3155-3161. 
Dauda, S.N., Ajayi, F.A. \& Ndor, E. (2008).Growth and yield of water melon (Citrulluslanatus) as affected by poultry manure application. Journal of Agriculture and Social Science, 4, 121-4.

De Brito-Alvarez, M.A., Gagne, S., \& Antoun, H. (1995). Effect of compost on rhizospheremicroflora of the tomato and on the incidence of plant-growth promoting rhizobacteria. Applied and Environment Microbiology, 61, 194-199.

Frankenberger, Jr., W.T. \&Arshad, M. (1995).Phytohormones in soils: microbial production and function. Marcel and Deckker Pub., New York, 503p.

GRP. (2010). Annual technical report 1999/2010. National Ginger Research Program (NGRP), Kapurkot, Salyan.

GRP. (2012). Annual technical report 2011/12. National Ginger Research Program (NGRP), Kapurkot, Salyan, Nepal.

GRP. (2014). Annual technical report 2013/14. National Ginger Research Program (NGRP), Kapurkot, Salyan, Nepal.

Jahan, F.N., Shahjalal, A.T.M.,Paul, A.K.,Mehraj, H., \& Jamal Uddin, A.F.M. (2014). Efficacy of vermicompost and conventional compost on growth and yield of cauliflower.Bangladesh Research Publications Journal, 10(1), 33-38.

K.C.,Govinda. (2003). Income generating ginger cultivation, an improved technology.Ginger Research Program, Kapurkot, Salyan.

Lawrence, B.M. (1984).Major tropical spices- Ginger (Zingiberofficinale Rose). Perfumer and flavorist, 9, 1-40.

Muscolo, A.,Bovalo, F., Gionfriddo, F., \& Nardi, F.(1999). Earthworm humic matter producesauxinlike effect on Daucuscarota cell growth and nitrate metabolism. Soil Biol.Biochem.,31, 13031311.

Poudyal, B.K. (2012).Jeevatu: One of the best bio-agents for the control of soft rot of ginger. 2nd International conference on environment science and biotechnology.IPCBEE, 48. 